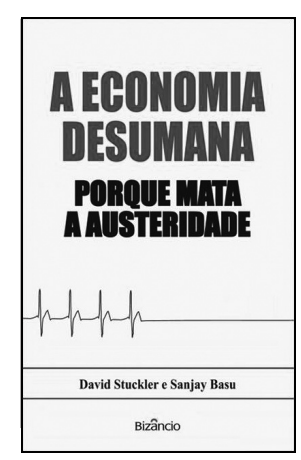

1 Universidade Federal de Santa Catarina (UFSC) Florianópolis (SC), Brasil. tania.kruger@ufsc.br

\title{
Stuckler D, Basu S. A economia desumana: porque mata a austeridade. Lisboa: Bizâncio; 2014.
}

Tânia Regina Krugerı

DOI: 10.1590/0103-1104201912022

Os autores procuram mostrar na obra como a saúde é afetada pelas crises econômicas, como as estatísticas apontam a sobrevivência e a não sobrevivência humana, por as políticas econômicas não serem meros dados matemáticos, e sim escolhas políticas em que taxas de crescimento, recessão e austeridade envolvem vidas humanas e a saúde de coletividades. O texto evidencia que as políticas econômicas por si só não são os agentes patógenos, mas, as 'causas das causas' da morbimortalidade e dos fatores que condicionam o grau de exposição a riscos de saúde. As forças econômicas definem quem tem mais probabilidade de beber em excesso, de contrair tuberculose, de sofrer depressão grave, de pegar doenças transmissíveis, de ficar desnutrido, sem emprego e habitação. Assim é que qualquer alteração no orçamento público pode ter um impacto poderoso sobre a saúde da população.

$\mathrm{O}$ interesse dos autores de conhecer os impactos das políticas de austeridade nos diferentes sistemas nacionais de saúde iniciou a partir da recessão de 2008 nos EUA. A obra apresenta análises de muitos países e de diferentes períodos recessivos, evidenciando como a saúde coletiva tem sido, historicamente, afetada pelos choques econômicos. A obra teve como questão norteadora:
Será realmente possível investir em programas de proteção social - no sistema de saúde, em programas de apoio aos doentes mentais, em subsídios de alimentação e apoios à habitação -, quando o país em causa enfrenta uma enorme situação de dívida pública?(15).

No âmbito das políticas capitalistas, os autores mostram que é possível solucionar o problema da dívida sem pôr em risco a saúde. Contudo, isso implica o financiamento de programas públicos (pensões, aposentadorias, saúde, apoios a doentes mentais, de alimentação, habitação, emprego e subsídios vários). Os resultados demonstram que os suportes a determinados programas de saúde contribuem de fato para reduzir a dívida e estimulam o crescimento da economia. "Cada dólar investido nesse tipo de programa produz um rendimento de três dólares em crescimento econômico"1(15). Por outro lado "os países que optam por profundos cortes orçamentais de curto prazo acabam por se ver numa situação de declínio econômico de longo prazo"'(15).

O livro apresenta como alguns países enfrentaram a crise e as repercussões na saúde pública. Na transição da República Soviética para a economia de mercado, houve uma crise demográfica "a esperança de vida dos homens 
russos caiu de 64 para 57 anos entre 1991 e 1994"1(54). Em 1998, o desemprego atingia 22\% e a taxa de pobreza era superior a $25 \%$ da população. As estatísticas mostram que os homens morriam por intoxicação alcoólica, suicídio e homicídios, mas os autores pretendem ir além das causas imediatas, para revelar a causa das causas, as mudanças sociais e econômicas.

Na era soviética, o trabalho representava mais do que um salário e uma ocupação. [...] Os planeadores soviéticos forneciam aos trabaIhadores serviços de saúde, creches e outros programas de apoio social. [...]. As pessoas não ganhavam muito, mas tinham estabilidade no emprego e uma série de benefícios ${ }^{\mathbf{1 6 0}}$.

À semelhança da Rússia, o Cazaquistão, a Letônia e a Estônia assistiram grandes aumentos de mortalidade, ao promoverem uma transição rápida para a economia de mercado (terapia de choque, recomendada pelo Banco Mundial), desenvolvendo programas radicais de privatização e enormes cortes nos orçamentos de proteção social. Nos países que preservaram seus sistemas de proteção durante a transição para a economia de mercado, como a Bielorrússia, a Eslovênia, a República Tcheca e a Polônia, seguindo a via gradualista, os efeitos negativos na saúde foram menos profundos.

A crise em 1997 no Leste da Ásia foi precedida por um influxo excepcional de capital estrangeiro, sem tecnologia e eficiência laboral. Na Tailândia e Indonésia, com a rigorosa política de austeridade, a população mal conseguia ganhar o mínimo para não morrer de fome, aumentaram as taxas de grávidas com anemia por causa da subnutrição, mortalidade por doenças infeciosas e suicídios. Na Coreia do Sul, aumentaram a pobreza, os problemas de saúde mental e o suicídio entre os homens. O FMI passou a ser conhecido como o Fundo da Mortalidade Infantil. Em paralelo, a Malásia resistiu às imposições do Banco Mundial e implementou um estímulo fiscal, reforçou as redes de segurança social de modo a amortecer o impacto da crise, preservou seus programas de vacinação e de apoio alimentar.

Na Europa, com a recessão de 2008, Grécia, Espanha, Portugal, Itália e Inglaterra foram os países que implantaram as políticas do ajuste. Particularmente na Grécia, cobaia europeia das políticas de austeridade, os custos humanos tornaram-se dramáticos, aumentaram $54 \%$ as infecções de HIV (Vírus da Imunodeficiência Humana), duplicaram suicídios, homicídios, toxicodependências e ressurgiu a malária. Com a sequência de terremotos financeiros, a democracia na Grécia foi suspensa por ordens da Troika, disparando o número de desempregados, de pessoas sem casa e de privatizações estatais. Em meio aos grandes protestos populares, como forma de resistência à crise extrema, assistiu-se o ressurgimento dos partidos de extrema direita, como o Aurora Dourada, com ataques racistas e a homossexuais e expurgo de imigrantes.

Nos Estados Unidos, no mesmo período, em função da franquia elevada, as pessoas deixavam de usar o plano de saúde em casos de prevenção e problemas não urgentes. "As pessoas usavam cada vez menos os centros de saúde e cada vez mais os serviços de urgência, quando se viam em situação grave"1(154). Os autores mostram que quem se beneficiou com a recessão foi um grupo de seguradoras de saúde que declararam aumento dos lucros posterior a 2008 .

E assim os ricos ficaram mais ricos, e os doentes mais doentes [...] por isso as seguradoras têm incentivos perversos para arregimentarem as pessoas mais saudáveis e eliminarem de sua carteira as pessoas mais doentes ${ }^{\mathbf{1 ( 1 5 5 )}}$.

Essa é a lei dos cuidados inversos. Os princípios fundadores do sistema de saúde inglês vêm sendo esquecidos com o governo tentando aproximar o National Health Service (NHS) do modelo americano, baseado no mercado. Apesar de negar a privatização, o governo está transferindo grandes áreas de cuidados de saúde para operadoras privadas, propondo que as pessoas com doenças crônicas 
decidam a quem confiar seus tratamentos, deixando-se levar pelos interesses predatórios das seguradoras.

Em síntese, a obra revela como as políticas de austeridade vão muito além da perda de emprego e casa, revelando-se um grande assalto à vida das pessoas. As diferentes experiências nacionais relatadas explicitam que uma catástrofe econômica, por pior que seja, não implica necessariamente em prejuízos para a saúde da população, desde que os governos a salvaguardem mediante políticas adequadas. Um fator que determina a saúde da população é a solidez das redes de segurança social. O perigo para a saúde pública não está na recessão per si, mas na austeridade, declaram os autores. "As recessões ferem, mas a austeridade mata"1(25). A título de exemplo, apresentam a situação da Islândia que, mesmo abalada pela crise bancária mundial, não teve o agravamento da mortalidade, pois optou por preservar seus programas de apoio social, realizando consulta à população que votou contra as medidas de um possível empréstimo do FMI. Em diferentes momentos históricos a mesma opção foi feita pela Suécia, Canadá, Japão, Austrália, Noruega e por alguns países europeus que rejeitaram o sistema baseado no mercado e preservaram os cuidados de saúde patrocinados pelo Estado.

A obra não apresenta exemplos de situação dos países da América Latina e África, mas com certeza essas realidades, com suas particularidades, tem historicamente sofrido com as políticas de austeridade. Para ampliar mais essas questões, fica a sugestão de temas para estudos de longo prazo de diferentes áreas das ciências humanas e sociais, e um alerta de que a conjuntura brasileira ultraconservadora que está matando o SUS e as nossas caras conquistas democrático-populares.

\section{Colaboradores}

Kruger TR, (0000-0002-7122-6088)* é responsável pela elaboração do manuscrito.

\section{Referência}

1. Stuckler D, Basu S. A Economia Desumana: porque mata a austeridade. Lisboa: Bizâncio; 2014.

Recebido em 02/11/2018

Aprovado em 14/12/2018

Conflito de interesses: inexistente

Suporte financeiro: não houve 